\title{
Paleomagnetism of the Cretaceous rocks from Cape Kronotskiy, East Kamchatka and reconstruction of terrane trajectories in the NE Pacific area
}

\author{
W. Harbert ${ }^{1}$, N. V. Tsukanov ${ }^{2}$, D. V. Alexeiev ${ }^{3}$, C. Gaedicke ${ }^{4}$, R. Freitag ${ }^{5}$, B. V. Baranov ${ }^{2}$, S. G. Skolotnev ${ }^{3}$, \\ W. Kramer ${ }^{6}$, and W. Seifert ${ }^{6}$ \\ ${ }^{1}$ National Energy Technology Laboratory and Geology and Planetary Science, University of Pittsburgh, Pittsburgh, PA, USA \\ ${ }^{2}$ P. P. Shirshov Institute of Oceanology, Russian Academy of Sciences, 36, Nakhimovsky Prospekt, 117997 Moscow, Russia \\ ${ }^{3}$ Geological Institute, Russian Academy of Sciences, Pyzhevsky Lane 7, 119017 Moscow, Russia \\ ${ }^{4}$ Bundesanstalt für Geowissenschaften und Rohstoffe, Stilleweg 2, 30655 Hannover, Germany \\ ${ }^{5}$ University Jena, Institute of Earth Sciences, Burgweg 11, 07749 Jena, Germany \\ ${ }^{6}$ GeoForschungsZentrum Potsdam, Telegrafenberg, 14473 Potsdam, Germany
}

\begin{abstract}
The Kamchatka Peninsula of northeastern Russia is located along the northwestern margin of the Bering Sea and consists of zones of complexly deformed accreted terranes. Paleomagnetic samples were collected for study from a Late Cretaceous aged locality at Cape Kronotskiy $\left(\lambda=54^{\circ} 44.8^{\prime} \mathrm{N}, \phi=162^{\circ} 1.29^{\prime} \mathrm{E}\right)$. Two components of magnetization were observed. During stepwise thermal demagnetization, the B-magnetic component was observed up to $600^{\circ} \mathrm{C}$ having a direction and associated uncertainty in stratigraphic coordinates of $D_{s}=300.7^{\circ}, I_{s}=48.7^{\circ}, \alpha_{95}=10.9^{\circ}$, kvalue $=11.8, \mathrm{n}=17$. The $\mathrm{B}$ component paleolatitude calculated from the Fisher mean in stratigraphic coordinates and associated statistics are $\lambda_{\text {obs }}=30.4^{\circ} \mathrm{N}$ or $\mathrm{S}, \lambda_{95}=8.9^{\circ}, \mathrm{n}=17$ (sites), $\mathrm{k}$-value $=11$. Our overall study paleolatitude result is similar to a previously reported paleomagnetic study completed within this unit. Terrane trajectories calculated using the finite rotation poles of Engebretson et al. (1985), which are corrected for either Pacific-hotspot drift or True Polar Wander hotspot-spin axis relative motion, show that the sampled unit represents a far traveled tectonostratigraphic terrane and support a model in which accretion (docking) events of this composite or superterrane with the North America plate occur at approximately $40 \mathrm{Ma}$.
\end{abstract}

Correspondence to: W. Harbert (harbert@pitt.edu)

\section{Introduction}

The Kamchatka Peninsula of northeastern Russia consists of zones of complexly deformed accreted terranes. The formation of the Kamchatka Peninsula by accretion and assemblage of oceanic and island-arc terranes, has been suggested during the last thirty years (Aleksandrov et al., 1975, 1980; Aleksandrov, 1978; Ruzhentsev et al., 1979, 1982; Byalobzhesky, 1979; Alekseyev, 1979, 1981, 1987; Kazimirov, 1985; Khramov, 1987, 1988; Gelman and Bychkov, 1988) and has been broadly studied using seismological, structural, paleontological, and paleomagnetic methods ( $\mathrm{Fu}-$ jita and Newberry,1982; Zonenshain et al., 1987, 1991; Sokolov, 1988, 1992; Stavsky et al., 1990; Astrahantzev et al., 1987; Grigoriev et al., 1986, 1987, 1990; Khanchuk et al., 1990; Krylov et al., 1989; Kazimirov et al., 1987; Didenko et al., 1993; Kovalenko, 2003). The goal of this study was to collect paleomagnetic data from an outermost tectonostragraphic terrane of the Kamchatka Peninsula.

The Kamchatka Peninsula of northeastern Russia consists of zones of complexly deformed accreted terranes. We studied rock units at Cape Kronotskiy, which is located on the eastern side of the Kamchatka Peninsula (Fig. 1). Presently, the Cape Kronotskiy region is an area of intense tectonic activity with an unknown number of interacting lithospheric plates and/or tectonic blocks. Even the present-day regional plate tectonic configuration of this area is uncertain as models consisting of two plates (e.g. Chapman and Solomon, 1976; Cook et al., 1986; Riegel et al., 1993), three plates (Cook et al., 1986; Riegel et al., 1993; Geist and Scholl, 1994), or two plates with numerous blocks (Mackey et al.,

Published by Copernicus Publications on behalf of the European Geosciences Union. 
1997; Gaedicke et al., 2000; Avé Lallemant and Oldow 2000; McElfesh et al., 2002) have been proposed.

Tectonic models for the evolution of this region can be broadly classified into oceanic-cratonal plate models in which only two plates interact in the Cape Kronotskiy region and multiple plate models in which a succession of oceanic plates (or blocks) interact in this region. Numerous authors have discussed the number, location, and configuration of tectonic plates in the Pacific basin in terms of seismic data, paleomagnetic data, magnetic isochrons, and fault orientation data (Chapman and Solomon, 1976; Parfenov and Natal'in, 1985, 1986; Natal'in et al., 1986; Engebretson et al., 1985; Watson and Fujita, 1985; Heiphetz et al., 1992a, b; Didenko et al., 1993; Riegel et al., 1993; Geist and Scholl, 1994; Mackey et al., 1997; Perchesky et al., 1997; Levashova et al., 1998; Chekhovich et al., 1999; Konstantinovskaia, 2001). By sampling paleomagnetic units from an out board terrane and then comparing these results with terrane trajectories calculated from finite-rotation models for known plates of the ancient pacific basin it was hoped that some insight could be gained into the past plate tectonic configuration of this complex region.

\section{Regional geology of the Kamchatka Peninsula}

The Kamchatka Peninsula is generally described as consisting of three distinct geologic regions: northern, central and southern. The northern and central regions are discussed below and are relevant because much of the previously collected paleomagnetic data comes from these geologic regions.

\subsection{Northern region}

The northern Kamchatka region, consisting mainly of the Koryak highlands, can be subdivided into three large tectonostratigraphic terranes, or superterranes, on the basis of composition, internal structure, age of rocks, and the age of the fault relationships. Moving inboard from the northwestern Bering Sea toward more interior Eurasia and the Okhotsk-Chukotka volcanic plutonic belt and the associated forearc deposits (the Udsko-Murgalsky and the Taigonosky terranes), are the Olyutorskiy superterrane, Ukelayat superterrane and Koryak superterrane (Sokolov et al., 1988; Grigoriev et al., 1990; Nokleberg et al., 1997, 1998) (Fig. 1).

The most outboard of tectonostratigraphic terranes which make up the northeast Kamchatka Peninsula is the Olyutorskiy superterrane. A major southeastward-dipping thrust fault boundary, the Vatyna thrust, juxtaposes the Olyutorskiy superterrane (sometimes referred to as "Olyutorskiy zone" or "Olyutorskiy system of nappes" in the Russian-language literature (Kazimirov et al., 1987) to the south and the late Cretaceous to Paleogene-aged Ukelayat superterrane to the north (Ermakov and Souprounenko, 1975; Mitrofanov, 1977; Aleksandrov et al., 1980; Mitrofanov and Sheludchenko, 1981; Alekseysev, 1987; Astrahantzev et al., 1987). The Olyutorskiy superterrane extends southward into the central Kamchatka region where it was referred to as the East Kamchatka superterrane (or the East Kamchatka zone in the earlier Russian-language literature) and is now referred to as the Achaivayamian-Valaginian arc (Fig. 1b) (Shapiro et al., 1984; Sokolov, 1992; Sokolov et al., 1988; Shapiro, 1995) although the outcrops of older rocks between the Koryak superterrane and the Achaivayamian-Valaginian arc are covered by Paleocene-Quaternary deposits. However, the continuity of this terrane boundary is clearly shown by regional residual magnetic anomalies (Harbert et al., 1998). A thrust, the Vatyna thrust, (Fig. 1b) extends into Kamchatka and is known in Kamchatka as the Lesnovsky thrust (Shapiro, 1976; Shapiro and Ganelin, 1988; Soloviev et al., 2002).

The Olyutorskiy superterrane in the northern-most Kamchatka region has been interpreted to represent an accretionary prism composed of at least three large, thrust fault bounded, terranes made of Late Albian to Campanian oceanic basalts and Late Campanian (?) MaastrichtianPaleocene island arc sedimentary, volcanic and plutonic units (Astrahantzev et al., 1987; Kazimirov, 1985; Kazimirov et al., 1987; Bogdanov and Fedorchuk, 1987; Krylov et al., 1989; Garver et al., 2000; Soloviev et al., 2002). In the central and southern Kamchatka Peninsula, corresponding terranes have been described in the Sredinny, Valaginsky, Tumrok and Kumroch mountain ranges (Shapiro, 1976, 1995; Shapiro et al., 1984; Sokolov et al., 1988; Grigoriev et al., 1990; Konstantinovskaia, 2001). The present interpretation of the Olyutorskiy superterrane is formation during the Late Campanian to Eocene as an island-arc (in the Russianlanguage literature the Achaivayam terrane or Achaivayam island-arc) on Albian to Early Campanian age Kula plate oceanic sea floor basement (the Vatyna terrane).

The Ukelayat superterrane (UKL) consists of a thick sequence of the Albian-Paleocene sedimentary-flysch rocks (Ermakov and Souprounenko, 1975; Mitrofanov, 1977; Aleksandrov et al., 1980; Mitrofanov and Sheludchenko, 1981; Alekseysev, 1987; Astrahantzev et al., 1987; Garver et al., 2000; Shapiro et al., 2001; Soloviev et al., 2002). Following the same general regional structure as the Olyutorskiy superterrane, this superterrane strikes southwestward into the Kamchatka Peninsula, where it is known as the West Kamchatka superterrane (West Kamchatka zone or Lesnovsky terrane in the Russian-language literature) (Shapiro and Ganelin, 1988; Sokolov, 1992; Sokolov et al., 1988; Grigoriev et al., 1990). Findings of the oldest fauna, Albian, are concentrated near the northern margin of the Ukelayat superterrane (within the Koryak mountains segment of this superterrane), or near western margin (within the Kamchatka Peninsula segment). The lower part of the stratigraphic sequence in the central part consists of sub-arkose sandstones and mudstones which contain Santonian-Coniacian 


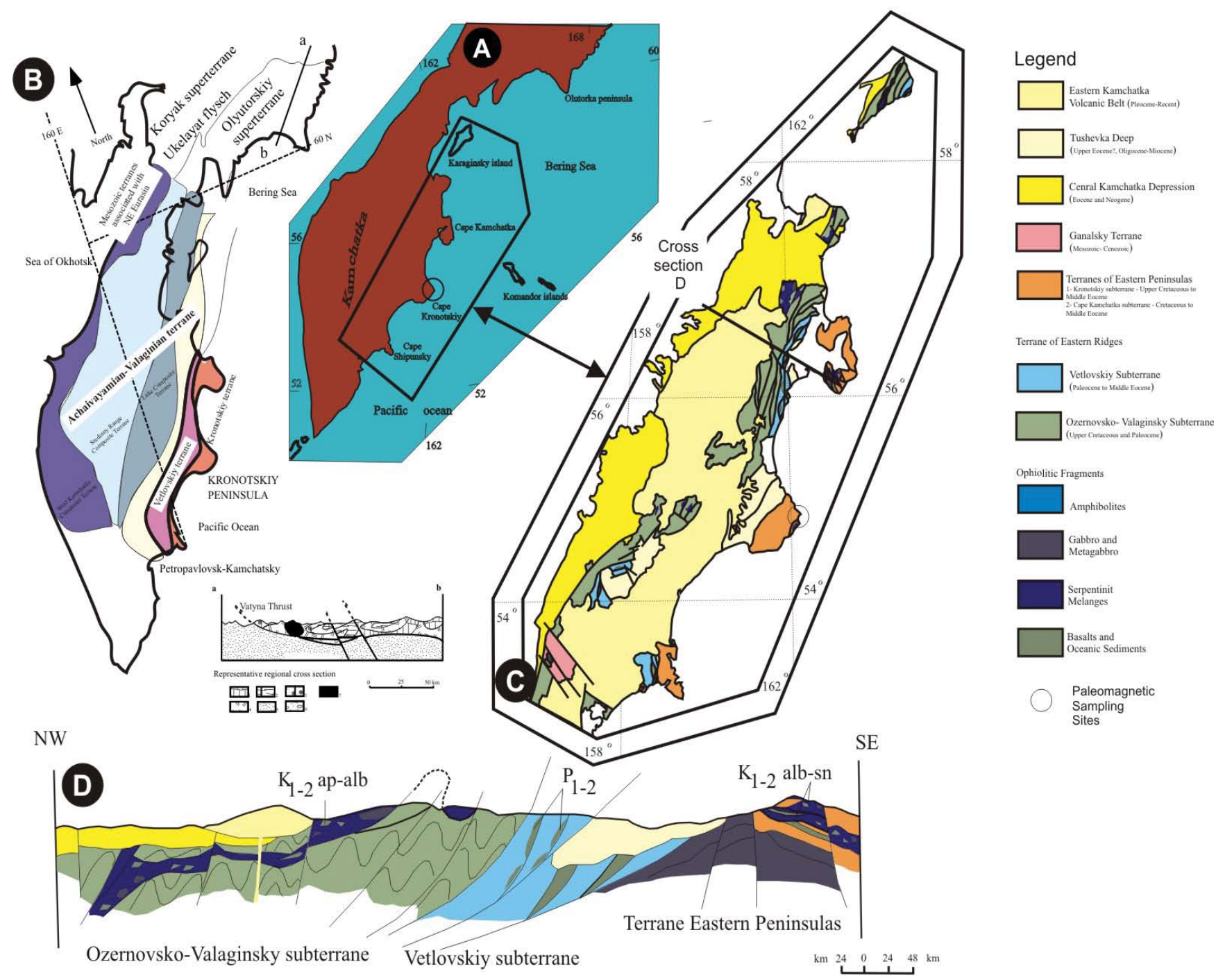

Fig. 1. A: Reference geographic map of the Kamchatka Peninsula. B: Simplified terrane map showing terranes associated with the margin of northeastern Eurasia (Koryak and UKL), the Olyutorskiy or Achaivayamian-Valaginian terrane, the Vetlovskiy (or Vetlovka) terrane and the Kronotskiy terrane (Alexeiev et al., 2006). The Vatyna thrust separates the Olyutorskiy superterrane and the Ukelayat flysch. and is shown on cross section $\mathrm{a}-\mathrm{b}$ (symbols for this subfigure are described in Heiphetz et al., 1994) C: Geologic map of the eastern portion of the Kamchatka Peninsula. D: Reference cross section of the eastern Kamchatka Peninsula (the approximate location of this composite cross section is shown in B). Our samples were collected from the Cape Kronotskiy region. Subfigures B, C and D are taken directly from Tsukanov and Fedorchuk (2000).

fauna (Ermakov and Souprounenko, 1975; Kazimirov et al., 1987). The Late Cretaceous rocks consist mainly of graywake turbidites interbedded with subarkose countourites. These are described in earlier Russian-language literature as a "two-component flysh" (Ermakov and Souprounenko, 1975). Campanian units contain layers of jaspers and cherts, interbedded with mudstones. Several flows of the high-Ti MORB-like tholeiites have been identified interbedded with the Campanian sandstones (Shapiro and Fedorov, 1985; Kazimirov et al., 1987). Locally, Late Cretaceous sandstones are interbedded with coal deposits. The UKL superterrane has been interpreted as having been formed in a marginal, or back-arc, basin between the Achaivayam member of the Olyutorskiy superterrane and a continental plate (Kazimirov et al., 1987). Recent fission-track grain ages from detrital zircons and sediment composition analysis have suggested that the UKL is composed of margin turbidite sequences, which formed in proximity of the Okhotsk-Chukotka volcanic plutonic arc (Garver et al., 2000; Shapiro et al., 2001; Soloviev et al., 2002).

Continuing inboard from the Ukelayat superterrane, the Koryak superterrane is thrust over the Ukelayat superterrane from the north. The Koryak superterrane is a complex composite terrane which consists of many tectonostratigraphic 
terranes (Migovich 1972; Nekrasov, 1976; Sokolov, 1988; 1992; Grigoriev et al., 1990; Khanchuk et al., 1990; Nokleberg et al., 1997, 1998). These terranes vary in age from the Middle Paleozoic to Early Cretaceous (Sokolov, 1988; 1992). Thrusts within the composite superterrane appear to be overlapped by Albian to Maastrichtian and Late Albian to Paleocene age sedimentary rocks.

The terrane boundaries are well expressed by regional magnetic and gravity field anomalies. Significant magnetic and relatively high gravity (Aleksandrov, 1978) anomalies allow calculation of the thickness of the Kuyul terrane. Models vary slightly, however generally all of the models Kuyul terrane are found to be that of a slab with thickness ranging from $0.9 \mathrm{~km}$ (Aleksandrov, 1978) to $2.0 \mathrm{~km}$ (Alekseyev, 1981) dipping to northwest at 10 to $15^{\circ}$. A magnetotelluric profile across the southern border of the terrane suggests penetration of the terrane-bounding fault to depths up to $10 \mathrm{~km}$ with physical properties of the rocks differing significantly across this fault zone (Moroz, 1987).

\subsection{Central region}

While more complex schemes have been proposed (Watson and Fujita, 1985), the region of central Kamchatka Peninsula has been divided into two main zones, the western (WZ; Western Zone Kamchatka superterrane) and eastern (EZ, Eastern Zone; East-Kamchatka superterrane) zones (Fig. 1). The boundary between these two regions is marked by a significant magnetic anomaly and a thrust system. This regional thrust, of western vergence in the northern part of Kamchatka, continues to the northeast where it may be traced to a major thrust system which divides the Koryak and Olyutorskiy superterranes discussed in the previous paragraphs. Much of the WZ complex consists of metamorphosed and strongly deformed, poorly dated, pre-Upper Cretaceous rocks of East and Central Kamchatka (Raznitsin et al., 1985; Tsukanov and Fedorchuk 1989; Tsukanov, 1991). The EZ complex is made up of thick stratigraphic sections of Upper Cretaceous and Paleocene rocks, (Lower Eocene rocks in East Kamchatka), which have been thrust and folded. Intense deformation of this complex may be related to collision events of other terranes with the Kamchatka Peninsula. A less-deformed complex is present in eastern-most Kamchatka, bordering the Pacific Ocean and Bering Sea. Folding and thrusting of pre-Pliocene rocks in a zone between the Kamchatka Peninsula and the Kronotskiy Peninsula implies that the latter (geographically including the Kamchatka and Shipunsky Peninsulas) may be the youngest terrane accreted to the Kamchatka landmass (Fig. 1).

In the WZ, the Upper Cretaceous is represented by thick stratigraphic sections composed of turbidites. The source material for these deposits has been suggested to have been the Okhotsk-Chukotka zone and an associated forearc. Volcanic material in sediments is scarce (at least in the
Campanian-Maastrichtian portion of the section); however blocks or lenses of basalt are present. The WZ is usually interpreted as a marginal basin not far away from the continental margin. In the eastern zone, EZ, volcanic flows (basalts, andesites, some associated sediments) are most common in the Late Cretaceous-Early Paleocene portion of the section. Some cherts and other silicious sediments are also found among volcanics (Zinkevich et al., 1990; Tsukanov, 1991; Shapiro et al., 1987; Shapiro, 1976). Sedimentary formations of considerable thickness of Paleocene and Lower Eocene, sometimes Upper Senonian, are also present in this zone. The EZ can be divided into five composite terranes, the Sredinny Range terrane, Litke terrane, East Ranges terrane, Vetlovskiy terrane, and East peninsulas or Kronotskiy terrane.

Previously the jaspers and basalts of SantonianCampanian age are the oldest rocks found in the Sredinny Range terrane (Shapiro et al., 1987), however recent U/Pb (SHRIMP) dating of zircons from a tuff layer within the lower portions of these units suggest they are Early Eocene in age (Soloviev et al., 2004). Conformably overlying this unit are Campanian-Maastrichtian sediments, lava flows, and Upper Maastrichtian to Paleocene turbidites, ages that are now clearly inconsistent with the recent $\mathrm{U} / \mathrm{Pb}$ ages. These rocks are exposed in thrust sheets of western vergence. The eastern limit of the terrane is now hidden under Late Cenozoic sedimentary cover of the Litke and Central Kamchatka basins but can be identified using regional residual magnetics. The Litke terrane is mainly covered by Late Cenozoic rocks with the exception of a limited area on a small Peninsula where the Upper Cretaceous island-arc series (flows and turbidites) outcrops (Shapiro, 1976; Kravchenko-Berezhnoy et al., 1990; Stavsky et al., 1990). The Litke subzone can be traced northward from Kamchatka into the Ilpinsky Peninsula of Koryak region, where tuffaceous Maastrichtian rocks are overlain without angular unconformity by a thick Paleocene sequence.

Within the Eastern Ranges terrane the Upper Santonian to Maastrichtian interval is represented by volcanic flows, mainly basalts, and turbidites which are conformably overlain by Paleocene flysch. These rocks are deformed into folds and thrusts of western vergence and unconformably overlain by Middle Eocene sediments.

The Vetlovskiy terrane is a narrow band of PaleoceneEocene sediments and oceanic basalts deformed into thrusts of eastern vergence and unconformably overlain by Middle Eocene sediments. The entire subzone has been interpreted to represent an ancient accretionary complex. As presented in Alexeiev et al. (2006) and Freitag et al. (2001) these volcanic and chert blocks immersed in a sheared terrigenous matrix may differ both in age and place of origin from the matrix. The zone is bounded on the east and west by largemagnitude trusts of eastern vergence.

The Eocene volcanic flow-sedimentary rocks of the Eastern Peninsulas, or Kronotskiy terrane, are similar in Cape 
Kamchatka, Cape Kronotskiy and Cape Shipunsky, whereas older rocks on each peninsula are very different. Post Coniacian time there was an active Kronotskiy arc, which was located to the outboard away from the continental plate margin of the Olyutorskiy arc. In this geodynamic model the Kula plate subducted under the Kronotskiy arc (Alexeiev et al., 2006). The Olyutorskiy and Kronotskiy arcs were separated by a back arc-basin (the Vetlovka basin during Paleocene and Eocene time). These arcs have been interpreted to have been located on a smaller scale plate (the "Vetlovka plate" suggested in Konstantinovskaia, 2001; see also Alexeiev et al., 2006). In this model, after northward motion on the Kula and Vetlovka plates, at about 50 Ma, this composite terrane collides with, and is accreted to the Eurasia plate (Astrahantzev et al., 1987; Kazimirov et al., 1987; Heiphetz et al., 1994; Shapiro, 1995).

At the Kronotskiy Peninsula locality paleomagnetic samples were collected from Late Cretaceous basaltic flows and interbedded fine grained sediments with visible bedding surfaces present within each sampled unit, outcropping within tidal coastal exposures. Paleomagnetic sites KRON01 to KRON18, with each site being represented by a collection of between 5 to 7 individually samples, were collected. During step-wise thermal demagnetization two components of remanent magnetization were observed at 18 sites (Fig. 2, Table 2). Previous paleomagnetic data show consistently lower than expected paleolatitudes from sampling sites throughout the Kamchatka region (Table 1).

\section{New paleomagnetic data}

Paleomagnetic samples were collected for study from the North Cape $\left(\lambda=54^{\circ} 44.8^{\prime} \mathrm{N}, \phi=162^{\circ} 1.29^{\prime} \mathrm{E}\right)$ locality (Fig. 2) on the Kronotskiy Peninsula. At each of 18 sampling localities a diamond-tipped, gasoline-powered core drill was used to collect samples, and when possible, orientation was determined using both magnetic and solar compasses. Orientation and geological data were communicated and recorded in both Russian and English languages for maximum clarity. The samples were measured in a 3-Axis 2-G superconducting rock magnetometer (SRM) at the University of Pittsburgh Paleomagnetic Laboratory (http://www.geology. pitt.edu). The SRM, along with both AF and thermal demagnetization equipment are located inside a magnetically shielded room (maximum field $<300 \mathrm{nT}$ ). The paleomagnetic specimens were measured within the SRM in two different orientations. The second orientation was obtained by reversing the specimen's Z-axis and rotating it $90^{\circ}$; and data from both orientations were combined into a resulting step measurement. After each set of measurements the samples were subjected to increasing increments of either $\mathrm{AF}$ (up to $95 \mathrm{mT}$ ) or thermal (up to $600^{\circ} \mathrm{C}$ ) demagnetization. Thermal cleaning was completed in an AST magnetically shielded (total field $<3-4 \mathrm{nT}$ in the cooling region) large capacity fur- nace. Principal component analysis was applied to the resultant magnetization vectors in geographic coordinates to determine best fitting linear and planar segments to the demagnetization data.

\subsection{Magnetic component A}

The A component of magnetization was observed between room temperature and approximately $250^{\circ} \mathrm{C}$ in many of the sites. Within the sampled units, the A component was not well grouped within sampling sites or between spatially adjacent units. Two polarities of A component were observed widely varying in declination. The Fisher estimate of kappa within sites where this component was observed varied between 170.1 to 2.2 , with only three sites having a Fisher estimate of kappa (Fisher, 1953) greater than 15, reflecting the scatter of this lower temperature of unblocking magnetic component. The site mean A component directions define a great circle with pole at $\lambda=-2.3^{\circ}, \phi=59.7^{\circ}$. If an incremental fold-test is applied to the Fisher averaged A site mean directions the highest $\mathrm{k}$-value is observed at $0 \%$ unfolding coordinates with associated statistics of $D=171.6^{\circ}$, $I=84.8^{\circ}, \alpha_{95}=27.1^{\circ}$, $\mathrm{k}$-value $=3.3, \mathrm{n}=13$ (sites), although the site mean directions clearly do not have a Fisher distribution. If Bingham statistics are applied a resulting overall mean of $D=26.4^{\circ}, I=86.3^{\circ}, \alpha_{95-1}=30.5^{\circ}, \alpha_{95-2}=67.8^{\circ}, \phi=53.7^{\circ}$, $\mathrm{n}=13$ (sites) is observed. This inclination is similar with that expected from the present day dipole magnetic field at the study location.

\subsection{Magnetic component B}

The B-magnetic component was observed up to $600^{\circ} \mathrm{C}$ at which thermal demagnetization temperature most samples have lost measurable remanent magnetization or new magnetic minerals appeared making interpretation of the characteristic remanence impossible (Fig. 3). The B magnetic component was observed within all sampled paleomagnetic sites at this locality. For our sites (see Table 2 for measured bedding attitudes and B component site level statistics), combining sites show the best grouping of B component was observed at $100 \%$ unfolding. Using Fisher (1953) statistics the resulting overall study B component and its associated uncertainty in geographic and stratigraphic coordinates are $D_{g}=288.3^{\circ}, I_{g}=57.9^{\circ}, \alpha_{95}=24.4^{\circ}, \mathrm{k}$ value $=3.1 ; D_{s}=300.7^{\circ}, I_{s}=48.7^{\circ}, \alpha_{95}=10.9^{\circ}$, k-value $=11.8$, $\mathrm{n}=17$ (sites). If Bingham statistics (Bingham, 1974) are applied a resulting overall mean of $D_{g}=285.6^{\circ}, I_{g}=81.2^{\circ}$, $\beta_{95-1}=12.6^{\circ}, \beta_{95-2}=63.4^{\circ}, \phi=172.1^{\circ} ; D_{s}=302.4^{\circ}, I_{s}=48.3^{\circ}$, $\beta_{95-1}=9.1^{\circ}, \beta_{95-2}=10.7^{\circ}, \phi=104.7^{\circ}, \mathrm{n}=17$ (sites) is observed (Fig. 4). The B component paleolatitude calculated from the Fisher mean in stratigraphic coordinates and associated statistics are $\lambda_{\text {obs }}=30.4^{\circ} \mathrm{N}$ or $\mathrm{S}, \lambda_{95}=8.9^{\circ}, \mathrm{n}=17$ (sites), k-value=11.1 (Fig. 5). The paleolatitude derived from this overall study is similar to those obtained from 
Table 1. Selected Paleomagnetic data from the Kamchatka region, northeastern Russia.

\begin{tabular}{|c|c|c|c|c|c|c|c|c|c|}
\hline Locality & Age & $\operatorname{Loc}^{\circ} \mathrm{N} /{ }^{\circ} \mathrm{E}$ & $\mathrm{N}$ & Demag/Test/Pol & $D_{s}$ & $I_{S}$ & $\alpha_{95}$ & $\lambda_{\text {obs }} \pm A_{95}$ & Terrane \\
\hline UB & Senonian & $63.0 / 179.5$ & 13 & $\mathrm{AF} / ? / \mathrm{M}$ & 263 & 82 & 13 & $74.3^{\circ} \pm 13^{\circ}$ & Al'Katvaamsky-Koryak \\
\hline PB & Cenomanian-Maastrichtian & $61.5 / 164.0$ & 10 & $\mathrm{AF} / ? / \mathrm{M}$ & 61 & 75 & 15 & $61.8^{\circ} \pm 15^{\circ}$ & Ainyn-Koryak \\
\hline UA & $66 \pm 4(\mathrm{~K} / \mathrm{Ar})$ & $61.5 / 170.5$ & 15 & $\mathrm{TH} / \mathrm{F} / \mathrm{R}$ & 321.4 & 70.8 & 10.8 & $55.1^{\circ} \pm 11^{\circ}$ & Olyutorskiy \\
\hline MB & $66 \pm 4(\mathrm{~K} / \mathrm{Ar})$ & $60.8 / 171.6$ & 16 & $\mathrm{AF}+\mathrm{TH} / \mathrm{F} / \mathrm{N}$ & 336.0 & 66.5 & 10.5 & $49.0^{\circ} \pm 11^{\circ}$ & Olyutorskiy \\
\hline $\mathrm{JB}$ & Campanian & $60.2 / 170.4$ & 17 & $\mathrm{AF}+\mathrm{TH} / \mathrm{F} / \mathrm{N}$ & 297.6 & 49.9 & 12.9 & $30.7^{\circ} \pm 13^{\circ}$ & Olyutorskiy \\
\hline VIII & $K_{2} \mathrm{cp}-\mathrm{m}$ & $60.3 / 170.6$ & $? ?$ & $\mathrm{TH} / \mathrm{F} / \mathrm{M}$ & 97 & 68 & 5 & $51.1^{\circ} \pm 8^{\circ}$ & Olyutorskiy \\
\hline VII & $K_{2} \mathrm{cp}-\mathrm{m}$ & $60.8 / 170.0$ & $? ?$ & $\mathrm{TH} / \mathrm{F} / \mathrm{M}$ & 88 & 65 & 5 & $47.0^{\circ} \pm 8^{\circ}$ & Olyutorskiy \\
\hline VI & $K_{2} \mathrm{cp}-\mathrm{m}$ & $61.6 / 171.2$ & $? ?$ & $\mathrm{TH} / \mathrm{M}$ & 80 & 67 & 8 & $49.7^{\circ} \pm 13^{\circ}$ & Olyutorskiy \\
\hline XIII & $P_{2}$ & $60.7 / 168.0$ & $? ?$ & $\mathrm{TH} / \mathrm{F} / \mathrm{M}$ & 348 & 74 & 4 & $60.2^{\circ} \pm 8^{\circ}$ & Olyutorskiy \\
\hline YA & L. Jur-E. Cret & $63.2 / 174.3$ & 5 & $\mathrm{TH} / \mathrm{F} / \mathrm{N}$ & 201.2 & 50.7 & 15.3 & $31.4^{\circ} \pm 15^{\circ}$ & Mainitsky-Koryak \\
\hline $\mathrm{KO}$ & L. Triassic & $62.5 / 174.5$ & 5 & $\mathrm{TH} / \mathrm{F} / \mathrm{M}$ & 186.5 & 41.5 & 15.4 & $23.9^{\circ} \pm 15^{\circ}$ & Khatyrsky-Koryak \\
\hline RY & L. Jurassic & $62.4 / 174.8$ & 4 & $\mathrm{TH} / \mathrm{F} / \mathrm{N}$ & 47.9 & 38.7 & 8.8 & $21.8^{\circ} \pm 9^{\circ}$ & Khatyrsky-Koryak \\
\hline SE & Senonian & $62.5 / 174.4$ & 5 & $\mathrm{TH} / \mathrm{F} / \mathrm{N}$ & 5.5 & 84.4 & 6.9 & $78.9^{\circ} \pm 7^{\circ}$ & Overlap Sequence Koryak \\
\hline GA1 & L. Bathonian-E. Callovian & $61.5 / 164.6$ & 15 & $\mathrm{TH} / \mathrm{F} / \mathrm{M}$ & 34.6 & 43.5 & 7.1 & $25.4^{\circ} \pm 7^{\circ}$ & Kuyul-Koryak \\
\hline GA2 & $93.6 \pm 2.7$ & $61.5 / 164.6$ & 4 & $\mathrm{TH} / \mathrm{F} / \mathrm{N}$ & 273.4 & 87.3 & 23.1 & $84.6^{\circ} \pm 24^{\circ}$ & Gankuvayamsky-Koryak \\
\hline KMP & $63.5 \pm 2.5$ & $56.3 / 163.3$ & 5 & $\mathrm{TH} / \mathrm{F} / \mathrm{M}$ & 28.0 & 60.2 & 12 & $41^{\circ} \pm .18^{\circ}$ & Kronotskiy \\
\hline KME1 & $44.5 \pm 1.5$ & $56.5 / 163.3$ & 7 & $\mathrm{TH} / \mathrm{F} / \mathrm{M}$ & 18.8 & 64.5 & 5.3 & $46^{\circ} \pm .49^{\circ}$ & Kronotskiy \\
\hline KME2 & $38 \pm 2$ & $56.5 / 163.3$ & 1 & $\mathrm{TH}$ & 359.4 & 66.9 & 11.2 & $49.5^{\circ} \pm 19^{\circ}$ & Kronotskiy \\
\hline KMR & Campanion-L. Paleocene & $56.6 / 162.3$ & 5 & $\mathrm{TH} / \mathrm{F} / \mathrm{R}$ & 337.5 & 67.4 & 7 & $50.2^{\circ} \pm 12^{\circ}$ & Vetlovskiy \\
\hline KMR1 & Oligocene-Miocene & $56.2 / 162.2$ & $21^{+}$ & $\mathrm{TH} / \mathrm{R}$ & 310 & 54 & 7 & $34.5^{\circ} \pm 10^{\circ}$ & Post-accretionary Complex \\
\hline KP1 & Eocene & $56.5 / 163.3$ & $31^{+}$ & $\mathrm{TH} / \mathrm{N}$ & 18 & 66 & 10 & $48.3^{\circ} \pm 16^{\circ}$ & Kronotskiy \\
\hline KRP & Eocene & $54.8 / 162.1$ & 4 & $\mathrm{TH} / \mathrm{F} / \mathrm{M}$ & 310 & 59 & 9 & $39.8^{\circ} \pm 13^{\circ}$ & Kronotskiy \\
\hline IXX & $K_{2} \mathrm{~m}-\mathrm{d}$ & $59.0 / 164.5$ & $? ?$ & $\mathrm{TH} / \mathrm{F} / \mathrm{M}$ & 332 & 62 & 5 & $43.2^{\circ} \pm 6^{\circ}$ & Eastern Ranges \\
\hline $\mathrm{XV}$ & $P_{2}^{3}-P_{3}^{1}$ & $60.0 / 165.0$ & $? ?$ & $\mathrm{TH} / \mathrm{F}$ & 338 & 80 & 9 & $70.6^{\circ} \pm 17^{\circ}$ & Litke \\
\hline XVII & $P_{2}^{2}$ & $59.8 / 164.9$ & $? ?$ & $\mathrm{TH} / \mathrm{F}$ & 299 & 73 & 10 & $58.6^{\circ} \pm 18^{\circ}$ & Litke \\
\hline XIV & $P_{2}^{1}$ & $60.0 / 165.2$ & $? ?$ & $\mathrm{TH} / \mathrm{F} / \mathrm{M}$ & 321 & 76 & 6 & $63.6^{\circ} \pm 11^{\circ}$ & Litke \\
\hline XVIII & $P_{1}^{2}$ & $59.8 / 164.8$ & $? ?$ & $\mathrm{TH} / \mathrm{F} / \mathrm{M}$ & 285 & 75 & 8 & $61.8^{\circ} \pm 15^{\circ}$ & Litke \\
\hline XVI & $K_{2}$ cp-d & $60.0 / 164.9$ & $? ?$ & $\mathrm{TH} / \mathrm{F} / \mathrm{M}$ & 299 & 61 & 6 & $42.1^{\circ} \pm 9^{\circ}$ & Litke \\
\hline KA & $66 \pm 4(\mathrm{~K} / \mathrm{Ar})$ & $59.0 / 164.2$ & 3 & $\mathrm{TH} / \mathrm{F} / \mathrm{M}$ & 330.3 & 64.8 & 15.0 & $46.7^{\circ} \pm 15^{\circ}$ & East Kamchatka** \\
\hline MA & L. Paleocene-Oligocene & $60.4 / 167.1$ & 5 & $\mathrm{TH} / \mathrm{F} / \mathrm{M}$ & 353.6 & 77.4 & 12.7 & $65.9^{\circ} \pm 13^{\circ}$ & East Kamchatka* \\
\hline IL & Paleogene & $59.8 / 164.9$ & 10 & $\mathrm{TH} / \mathrm{F} / \mathrm{M}$ & 307.3 & 72.9 & 8.8 & $58.4^{\circ} \pm 9^{\circ}$ & East Kamchatka* \\
\hline
\end{tabular}

References: Pechersky (1970) UB, PB; Bazhenov et al. (1992a, b), KMR, KP1, KRP; Heiphetz et al. (1993b) UA, MB, and JB; Didenko et al. (1993) YA, KO, RY, and SE; KA, MA, and IL; Heiphetz et al. (1993a) GA1 and GA2; Pechersky et al. (1997) KMP, KME1, KME2; Levashova et al. (1997), KMR; D. V. Kovalenko (personal communication, 1998), Kovalenko (1992, 1996), and Kovalenko and KravchenkoBerezhnoy (1999) VIII, VII, VI, XIII, IXX, XV, XVII, XIV, XVII, XVI.

+ Statistics calculated using $\mathrm{N}=$ number of samples.

* East Kamchatka superterrane can be correlated with the Olyutorskiy superterrane.

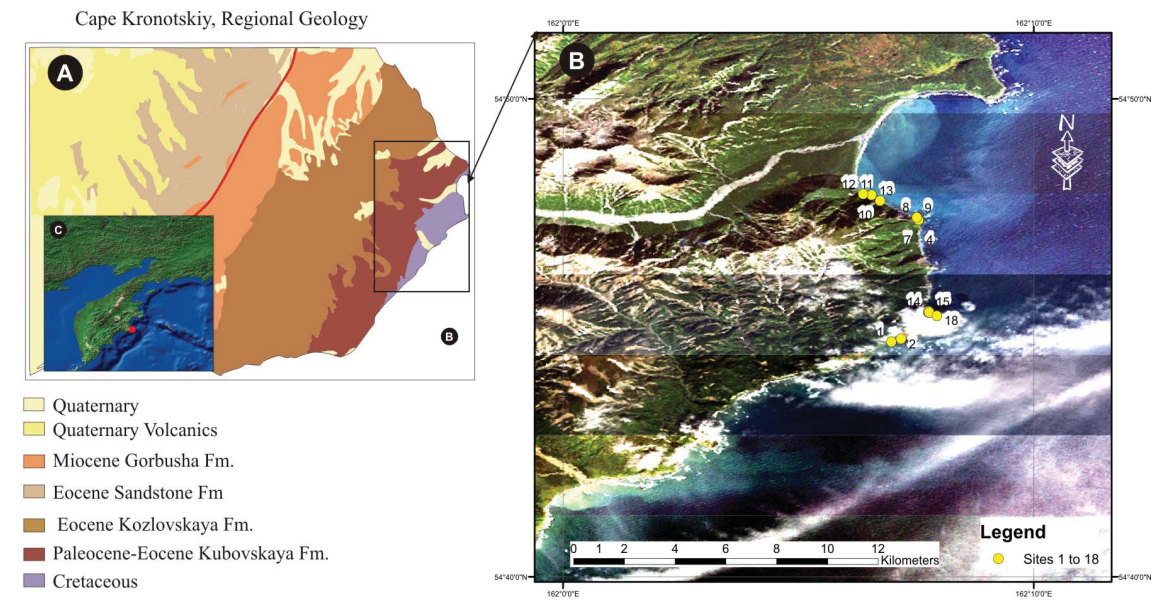

Fig. 2. A: Simplified geology and local stratigraphy of the units on Cape Kronotskiy B: A regional LANDSAT 7 image showing the sampling sites and $\mathbf{C}$ : A geographic reference map showing the location of the Kamchatka Peninsula in the northeastern Pacific basin. 
Table 2. Northwestern Cape Kronotskiy region component B site mean directions and associated site statistics.

\begin{tabular}{lllrlllrlr}
\hline Site & Latitude $(\mathrm{N})$ & Longitude $(\mathrm{E})$ & Strike & Dip & Dir & Inc $_{g}$ & Dec $_{g}$ & $\mathrm{~N}$ & Kappa $_{g}$ \\
\hline KRON01 & 54.7488 & 162.1163 & 48.95 & 20.0 & $\mathrm{~S}$ & 38.3 & 325.3 & 7 & 13.3 \\
KRON02 & 54.7499 & 162.1198 & 338.95 & 9.0 & $\mathrm{~N}$ & 42.2 & 297.7 & 3 & 6.1 \\
KRON03 & 54.7911 & 162.1261 & 21.95 & 38.5 & $\mathrm{~S}$ & -0.4 & 266.1 & 6 & 147.0 \\
KRON04 & 54.7910 & 162.1260 & 21.95 & 38.5 & $\mathrm{~S}$ & -17.3 & 277.1 & 2 & 85.3 \\
KRON05 & 54.7913 & 162.1259 & 21.95 & 38.5 & $\mathrm{~S}$ & -8.6 & 295.0 & 5 & 123.0 \\
KRON06 & 54.7913 & 162.1259 & 18.95 & 47.0 & $\mathrm{~S}$ & -6.0 & 303.0 & 4 & 6.2 \\
KRON08 & 54.7913 & 162.1259 & 42.95 & 22.0 & $\mathrm{~S}$ & 41.8 & 290.1 & 6 & 45.0 \\
KRON09 & 54.7922 & 162.1253 & 39.95 & 33.0 & $\mathrm{~S}$ & 33.0 & 257.8 & 5 & 52.3 \\
KRON10 & 54.7922 & 162.1253 & 236.94 & 25.5 & $\mathrm{~N}$ & 84.2 & 161.9 & 6 & 963.0 \\
KRON11 & 54.7999 & 162.1093 & 229.94 & 48.0 & $\mathrm{~N}$ & 78.4 & 86.3 & 6 & 334.8 \\
KRON12 & 54.7999 & 162.1093 & 236.94 & 25.5 & $\mathrm{~N}$ & 66.6 & 174.0 & 3 & 712.5 \\
KRON13 & 54.8003 & 162.1063 & 236.94 & 85.0 & $\mathrm{~N}$ & 63.8 & 143.4 & 4 & 89.3 \\
KRON14 & 54.8003 & 162.1063 & 214.96 & 52.0 & $\mathrm{~W}$ & 83.6 & 71.5 & 6 & 453.6 \\
KRON15 & 54.7980 & 162.1123 & 214.96 & 52.0 & $\mathrm{~W}$ & 86.7 & 219.8 & 6 & 1757.6 \\
KRON16 & 54.7593 & 162.1294 & 214.96 & 52.0 & $\mathrm{~W}$ & 83.4 & 152.3 & 6 & 324.6 \\
KRON17 & 54.7593 & 162.1294 & 214.96 & 52.0 & $\mathrm{~W}$ & 76.8 & 70.4 & 3 & 427.6 \\
KRON18 & 54.7593 & 162.1294 & 54.96 & 21.0 & $\mathrm{~S}$ & -20.4 & 144.3 & 2 & 5.1 \\
\hline
\end{tabular}

Study mean direction $D_{S}=300.7, I_{S}=48.7, \alpha_{95}=10.9$, Fisher estimate of kappa=11.8, N (sites)=17, percent unfolding=100\%.

previously reported paleomagnetic studies from this sampling region (Table 1; result KMR; Levoshova and Bazhenov, 1997).

\subsection{Interpretation of previous and new paleomagnetic data}

Our results from the Kronotskiy region of the eastern Kamchatka Peninsula are consistent with a regional dataset showing that the terranes presently making up the peninsula are far traveled. Data from the Khatyrka terrane (KO and RY), Kuyul (GA1), Maynitsky terrane (YA), and sedimentary overlap sequences (SE, UB and PB) from the Koryak superterrane of northern Kamchatka constrain the Late Paleozoic and Mesozoic paleolatitudes of these terranes (Table 1). The paleolatitudes from the Khatyrka and Maynitsky terranes are anomalously low, while the paleomagnetic pole from the Senonian and Cenomanian-Maastrichtian sedimentary sequences suggests deposition of these units at the expected paleolatitudes with respect to either North American or Eurasian Apparent Polar Wander Paths (APWP), thus providing a minimum estimated accretion age for the overlapped terranes.

Paleomagnetic data collected from sedimentary rocks of Senonian and Cenomanian-Maastrichtian age, which overlap those from Al'katvaamsky terrane (UB), Penzhina Bay (PB) and Khatyrka terrane (SE) suggest that these sediments were all deposited at high paleolatitude, along the southeastern edge on the Eurasia plate. There is no significant difference between the expected and observed paleolatitudes (Table 1). This suggests that accretion of the Koryak superterrane occurred prior to Senonian-Cenomanian-Maastrichtian time.
Outboard of the Koryak superterrane paleomagnetic data show that the Olyutorskiy superterrane also consists of far traveled tectonostratigraphic terranes. The difference between the Olyutorskiy (UA, MB, and KA) terrane localities paleolatitudes for the Late Cretaceous-Paleocene are insignificant at the $95 \%$ confidence limits and consistent with paleomagnetic results VIII, VII, and VI (Table 1). Studies from Upper Apuka (UA) shows a latitudinal anomaly of $23.0^{\circ} \pm 18.0^{\circ}$ and $28.3^{\circ} \pm 17.0^{\circ}$ for the Machevna Bay (MB) localities, suggesting that Maastrichtian tuffs and tuffaceous

sandstones originated significantly to the south of either reference plate. Rotational and flattening statistics (Demarest, 1983) calculated with respect to the $67 \mathrm{Ma}$ North America paleomagnetic reference pole (Irving and Irving, 1982) shows that these rocks formed at a significant distance from the North America continent. Calculated latitudinal anomalies are $20.5^{\circ} \pm 14.7^{\circ}$ for the Upper Apuka and $26.2^{\circ} \pm 13.4^{\circ}$ for the Machevna Bay localities. The choice of the paleomagnetic reference pole (reference continent) does not effect to the interpretation of the displacement: the Maastrichtian island-arc where these rocks originated was situated $20^{\circ}-30^{\circ}$ south from both North America and Eurasia continents. The Olyutorskiy (JB) result is significantly shallower than expected from either APWP, with an observed paleolatitude of $32^{\circ}$ and a difference between expected and observed paleolatitudes of $42.6^{\circ} \pm 21.8^{\circ}$ (Table 1 ).

In order to model these observed paleolatitudes we have used plate kinematic models of the past motions of oceanic and continental plates in the Northern Pacific Basin (Engebretson et al., 1985) and the modeling techniques described in Debiche et al. (1987). 

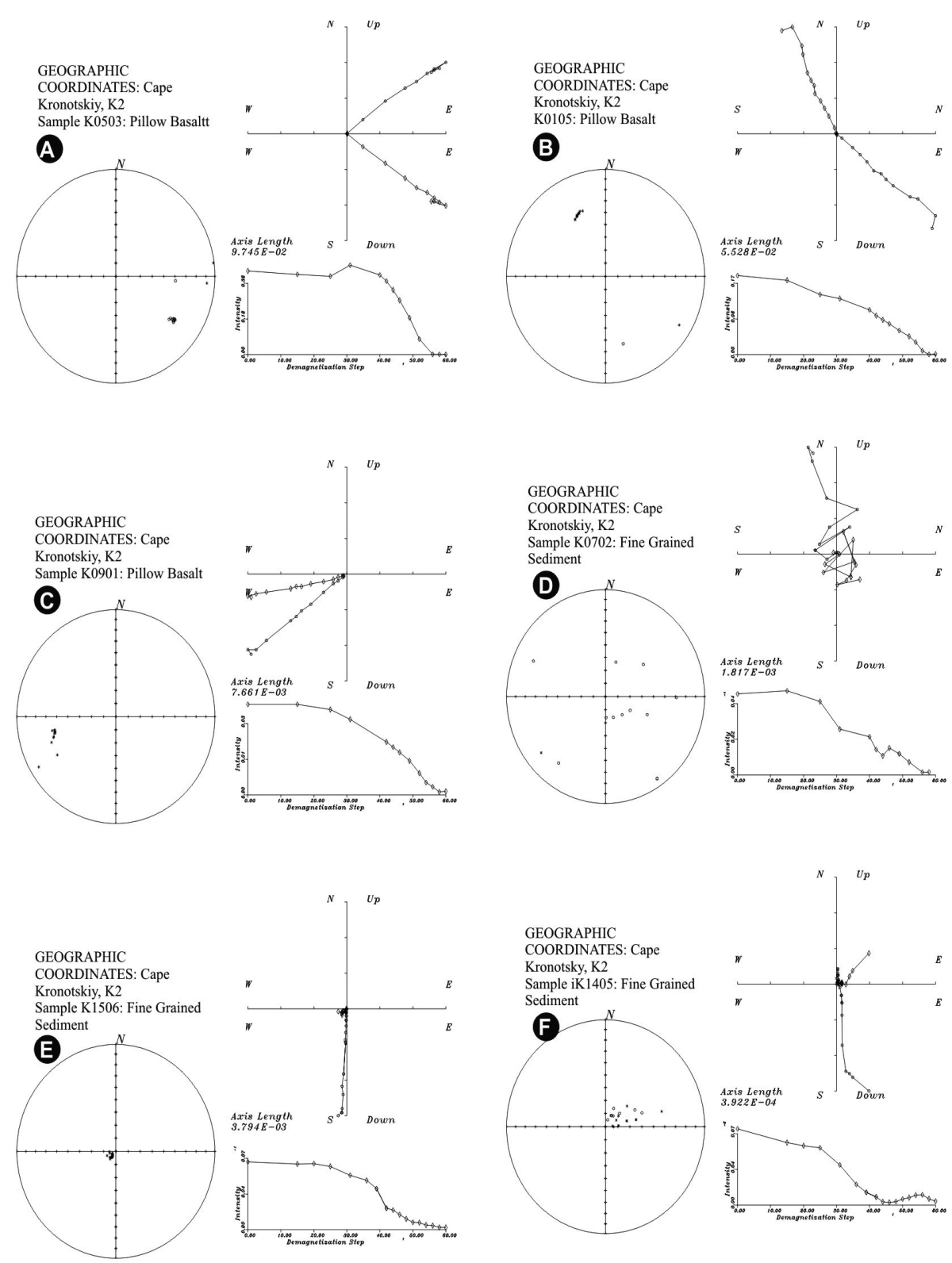

Fig. 3. Representative orthogonal vector plots, magnetic intensity decay diagrams and equal-area stereographic projects for selected stepwise thermal demagnetization data for samples A K0503,B K0105, C K0901, D K0702, E K1506 and F K1405. Lower hemisphere demagnetization directions are shown by the "*” symbol on the equal area stereographic projections, orthogonal vector plot projections onto the vertical plane are shown by circles, and onto the horizontal plane by diamonds.

\section{Modeled accretionary terrane trajectories}

To model the paleomagnetic results and the associated paleolatitudes we constructed model apparent polar wander paths (MAPWP) and terrane trajectories (Debiche et al., 1987; Cox and Hart, 1986). This method consists of rotating APWP reference points into a terrane frame of reference using finite rotations between the Eurasian and the ancient Izanagi and Farallon oceanic plates. Recently, data supporting a modification to this analysis, true polar wander and/or relative displacement of regional hotspot reference frames, have been presented (Tarduno and Gee, 1995; Torsvik et al., 2002; Courtillot et al., 2003; Tarduno et al., 2003). In this section terrane trajectory analysis, which incorporates these two modifications, will be presented. The construction of terrane trajectories is based upon the application of finite plate rotations to paleomagnetic results and details of our models and their calculation are given in Appendix A. 


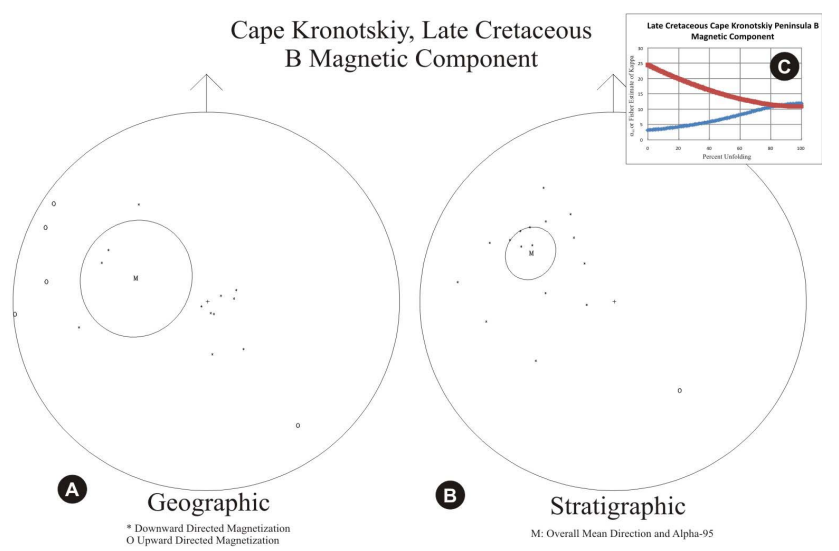

Fig. 4. Equal area site mean stereographic projection plots of the $B$ magnetic component in A geographic coordinates, $\mathbf{B}$ stratigraphic coordinates, and $\mathbf{C}$ the Fisher estimate of Kappa and Fisher estimate $\alpha_{95}$ during stepwise unfolding. On these plots (X), presentday magnetic field direction $(\mathrm{P})$, component $\mathrm{B}$ mean direction $(\mathrm{M})$ and $\alpha_{95}$ circle of confidence shown in geographic and $100 \%$ unfolding coordinates. Upper hemisphere directions are shown with "O" symbols. Site mean B component numerical data are presented in Table 2.

We find that after these modifications the expected paleolatitude corresponding to this displacement history is shallower than paleomagnetic results (in the $30 \mathrm{Ma}$ accretion model) but better agrees with our paleomagnetic results in the $40 \mathrm{Ma}$ accretion model. Assuming the later displacement history and collision to North American plate we expect a paleolatitude of between $45^{\circ}$ and $25^{\circ} \mathrm{N}$ between 60 to $80 \mathrm{Ma}$ matching our observation of $\lambda_{\text {obs }}=30.4^{\circ} \mathrm{N}$ or $\mathrm{S}, \lambda_{95}=8.9^{\circ}$, $\mathrm{n}=17$ (sites). Our paleomagnetic data was collected from the Kronotskiy arc, which is a distinct terrane from the Olyutorskiy, however, our paleomagnetic results are compatible with an earlier accretion for this terrane than previously interpreted. We interpret our paleomagnetic data and revised terrane trajectory models to show that fragments of an island arc are present in the East Kamchatka superterrane that accreted to a cratonal plate in this region during the Eocene.

\section{Conclusions}

We have observed a characteristic B component in Late Cretaceous aged geologic units at Cape Kronotskiy. The resulting paleolatitude and associated uncertainty in stratigraphic coordinates are $D_{s}=300.7^{\circ}, I_{s}=48.7^{\circ}, \alpha_{95}=10.9^{\circ}$, k-value $=11.8, \mathrm{n}=17$ (sites). The B component paleolatitude calculated from the Fisher mean in stratigraphic coordinates and associated statistics are $\lambda_{\mathrm{obs}}=30.4^{\circ} \mathrm{N}$ or $\mathrm{S}, \lambda_{95}=8.9^{\circ}, \mathrm{n}=17$ (sites), $\mathrm{k}$-value $=11$. Our paleomagnetic data from the Kronotskiy Peninsula in eastern Kamchatka agree well with the highest unblocking temperature direction presented in study
Cape Kronotskiy: Late Cretaceous

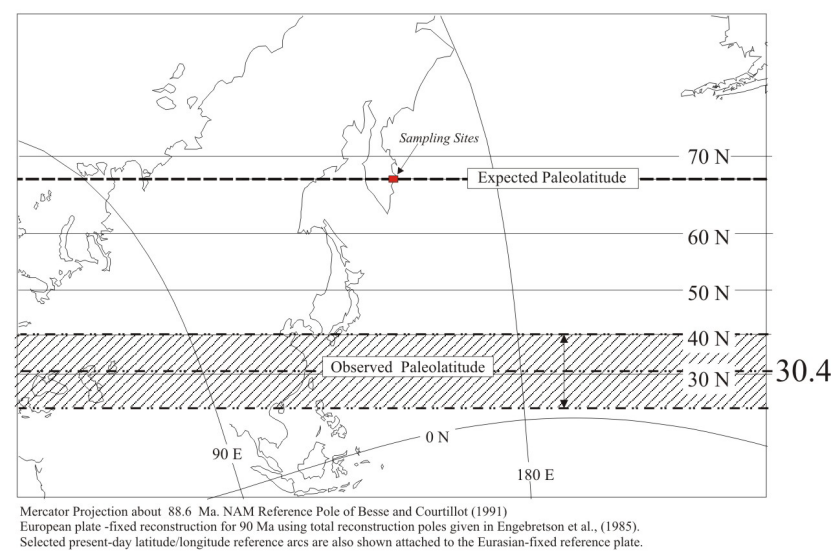

Fig. 5. The paleolatitude and uncertainty calculated from the observed magnetic component B are shown in a Mercator projection about the $89 \mathrm{Ma}$ NAM Reference pole of Besse and Courtillot (1991).

KMR (Levashova and Bazhenov, 1997). These paleomagnetic data are consistent with a terrane trajectory model of the Kronotskiy superterrane, in which relative displacement of the Hawaii hotspot, or True Polar Wander, are incorporated.

\section{Appendix A}

\section{Modeling finite rotation trajectories}

An efficient notation for finite rotations has been developed and well described so that relative motion of the Pacific hotspot framework can be incorporated into terrane analysis of the Kronotskiy B component paleomagnetic result. Understanding of the basics of finite pole rotations is useful in understanding this analysis and its inherent assumptions; this summary is based upon presentations in Engebretson et al. (1985), Debiche et al. (1987) and Cox and Hart (1986).

Total reconstruction poles (TRP) represent the pole, which rotates points on the earth's surface from their present location to an ancient location, in a particular plate reference frame between two time intervals. For example, the TRP, which rotates the Kula plate from its present position to its position at $73 \mathrm{Ma}$ with respect to the Pacific plate is shown as ${ }_{\mathrm{PAC}}^{0} \Re_{\mathrm{KUL}}^{73}$. In this notation the fixed plate is the Pacific plate, while the mobile plate, the Kula in this example moves from a present to a past, $73 \mathrm{Ma}$, position. The TRP pole, which spatially displaces surface points from ancient to present positions, is shown as ${ }_{\mathrm{KUL}}^{73} \mathfrak{R}_{\mathrm{PAC}}^{0}$. The Euler pole in computations is either expressed by a rotation matrix or quaternion. TRPs can be combined, however, because there is not a commutative property in TRP finite rotations, the order of rotations is critical. Notation showing the proper combination of 
TRPs resulting in a description of motion of the Kula (KUL) plate in a North America plate (NAM) fixed reference frame, in which a matrix operation is shown with the circle/plus symbol, is shown in (1)

${ }_{\mathrm{NAM}}^{0} \Re_{\mathrm{KUL}}^{70}={ }_{\mathrm{NAM}}^{0} \Re_{\mathrm{PAC}}^{70} \oplus_{\mathrm{PAC}}^{0} \Re_{\mathrm{KUL}}^{70}$

Or in the hotspot fixed reference frame,

${ }_{\mathrm{HSP}}^{0} \Re_{\mathrm{KUL}}^{70}={ }_{\mathrm{HSP}}^{0} \Re_{\mathrm{PAC}}^{70} \oplus_{\mathrm{PAC}}^{0} \Re_{\mathrm{KUL}}^{60} \oplus_{\mathrm{PAC}}^{60} \Re_{\mathrm{KUL}}^{70}$

In (2) the finite rotation pole is of a different type and defined as a stage pole, ${ }_{\mathrm{PAC}}^{60} \Re_{\mathrm{KUL}}^{70}$. A stage pole represents the finite rotation, which moves features on one plate with respect to another plate, between two intervals of time $t_{1}$ and $t_{2}$ : An assumption is made that the Euler pole for a plate pair remains fixed during stages and changes locations, or "jumps" between stages. This assumption is supported by detailed analysis of oceanic magnetic isochrones (Engebretson et al., 1985). TRPs can easily be converted to stage poles and stage poles to TRPs. Associated with the concept of stage poles is an important property of finite rotation algebra,

${ }_{A}^{T 2} \Re_{B}^{T 1} \neq\left(-\left({ }_{B}^{T 2} \Re_{A}^{T 1}\right)\right)$

This algebraic property at first glance seems violated by the algebraic identify

$A^{T} \Re_{B}^{0}=\left(-{ }_{A}^{0} \Re_{B}^{T}\right)$

However, it is not inconsistent with Eq. (3) because total reconstruction poles all share the same present-day reference system at $t=0$ (present day) time (Cox and Hart, 1986).

In our analysis we first convert TRPs to Stage Poles. The TRPs are taken directly from the magnetic isochron analysis of Pacific basin oceanic plate kinematics published by Engebretson et al. (1985). For each plate pair these stage poles are then interpolated to a series of stage poles, each $0.1 \mathrm{Ma}$ in duration by combining discrete position and negative signed finite rotations. The specific plate kinematic history of the displaced terrane is then used to guide the editing and then combination of $0.1 \mathrm{Ma}$ duration stage poles into a file which is then used to calculate total reconstruction poles at $0.1 \mathrm{Ma}$ time steps. These TRPs now describe the displacement history of the terranes in eastern Kamchatka with respect to translation on specific oceanic plates. From the TRPs and assuming a point of beginning the terrane trajectory is calculated (Debiche et al., 1987). The expected paleomagnetic inclination, declination and paleolatitude can be easily calculated for the modeled displacement history.

As seen earlier there are assumptions, such as the "jumping" nature of stage poles, in this methodology. A key assumption in the analysis of Engebretson et al. (1985) was the fixed nature of the hotspot coordinate framework for the Africa and Pacific plates. If the Atlantic/Africa region hotspot frame is noted as $\mathrm{HS}_{1}$ and the Pacific region hotspot finite rotation frame as $\mathrm{HS}_{2}$, the hotspot fixed finite rotation poles were calculated as:

${ }_{\mathrm{NAM}}^{0} \Re_{\mathrm{KUL}}^{T 1}={ }_{\mathrm{NAM}}^{0} \Re_{\mathrm{AFR}}^{T 1} \oplus\left(-\left({ }_{\mathrm{HS} 1}^{0} \Re_{\mathrm{AFR}}^{T 1}\right)\right) \oplus_{\mathrm{HS} 2}^{0} \Re_{\mathrm{PAC}}^{T 1} \oplus_{\mathrm{PAC}}^{0} \Re_{\mathrm{KUL}}^{T 1}$

Stephan Mueller Spec. Publ. Ser., 4, 313-327, 2009
The fixed hotspot assumption is inherent in this analysis:

$0={ }_{\mathrm{HS} 1}^{0} \Re_{H S 2}^{T 1}$

Models of hotspot-spin axis relative motion have been published (Tarduno and Gee, 1995; Torsvik et al., 2002; Courtillot et al., 2003; Tarduno et al., 2003). The results of Torsvik et al. (2002), does not alter terrane trajectories although the predicted paleolatitudes are shifted. Terrane trajectories modified to include the TRP presented in Torsvik et al. (2002) are shown in Fig. A1.

Recently new paleomagnetic data from the Hawaiian hotspot, innovatively collected, analyzed and interpreted by Tarduno et al. (2003), have been presented and interpreted to show the relative displacement of the Hawaii hotspot with respect to the geographic axis (GXS). These data only constrain latitudinal displacement and have been interpreted to show motion of the Hawaiian hotspot (the HS2 finite rotation pole framework) with respect to the geographic axis. A finite-rotation based model of this displacement can be incorporated into terrane trajectory analysis. A model of ${ }_{\text {GXS }}^{0} \Re_{H S 2}^{T 1}$ finite rotation poles is used and terrane trajectories are then calculated with respect to each of these finite rotation pole models. Earlier finite rotation pole models incorporated the explicit assumption of

$0={ }_{\mathrm{GXS}}^{0} \Re_{\mathrm{HS} 1}^{T 1}$

It is straightforward to incorporate this simple modification of the finite rotation pole analysis by adding the additional finite rotation stage pole describing this rotation given by

${ }_{\mathrm{GXS}}^{T 1} \Re_{\mathrm{HS} 2}^{T 2}$

The unit vector Euler pole is calculated from the cross product of $\hat{\boldsymbol{A}}_{1} \times \hat{\boldsymbol{A}}_{2}=\boldsymbol{C}$, where c represents the unit vector Euler pole. The finite rotation stage pole is determined by combining with the Euler pole the rotation angle defining ${ }_{\mathrm{GXS}}^{T 1} \Re_{\mathrm{HS} 2}^{T 2}$. In this stage pole calculation $\hat{\boldsymbol{A}}_{1}$ and $\hat{\boldsymbol{A}}_{2}$ represent the present day and interpreted positions of the Hawaii hotspot, where $\hat{\boldsymbol{A}}_{2}$ satisfies the latitude displacement presented in Tarduno et al. (2003). Using this ${ }_{\mathrm{GXS}}^{45} \Re_{\mathrm{HS} 2}^{85}$ model as the stage pole describing geographic axis - Hawaii hotspot displacement this new term may be incorporated in our analysis as shown by,

$$
\begin{aligned}
\stackrel{\mathrm{NAM}}{1} 1_{\mathfrak{R}_{\mathrm{KUL}}^{T 2}=} & \underset{\mathrm{NAM}}{T 1} \Re_{\mathrm{AFR}}^{T 2} \oplus\left(-\left({ }_{\mathrm{HS} 1}^{T 1} \Re_{\mathrm{AFR}}^{T 2}\right)\right) \oplus_{\mathrm{HS} 1}^{T 1} \Re_{\mathrm{GXS}}^{T 2} \\
& \oplus_{\mathrm{GXS}}^{T 1} \Re_{\mathrm{HS} 2}^{T 2} \oplus_{\mathrm{HS} 2}^{T 1} \Re_{\mathrm{PAC}}^{T 2} \oplus_{\mathrm{PAC}}^{T 1} \Re_{\mathrm{KUL}}^{T 2}
\end{aligned}
$$

Equation (9) incorporates within the North America fixed terrane trajectories an estimate of geographic axis-Hawaii hotspot relative motion. This analysis can be extended to include Atlantic/Africa region hotspot absolute motion where

$0 \neq_{\mathrm{GXS}}^{0} \Re_{H S 1}^{T 1}$ 


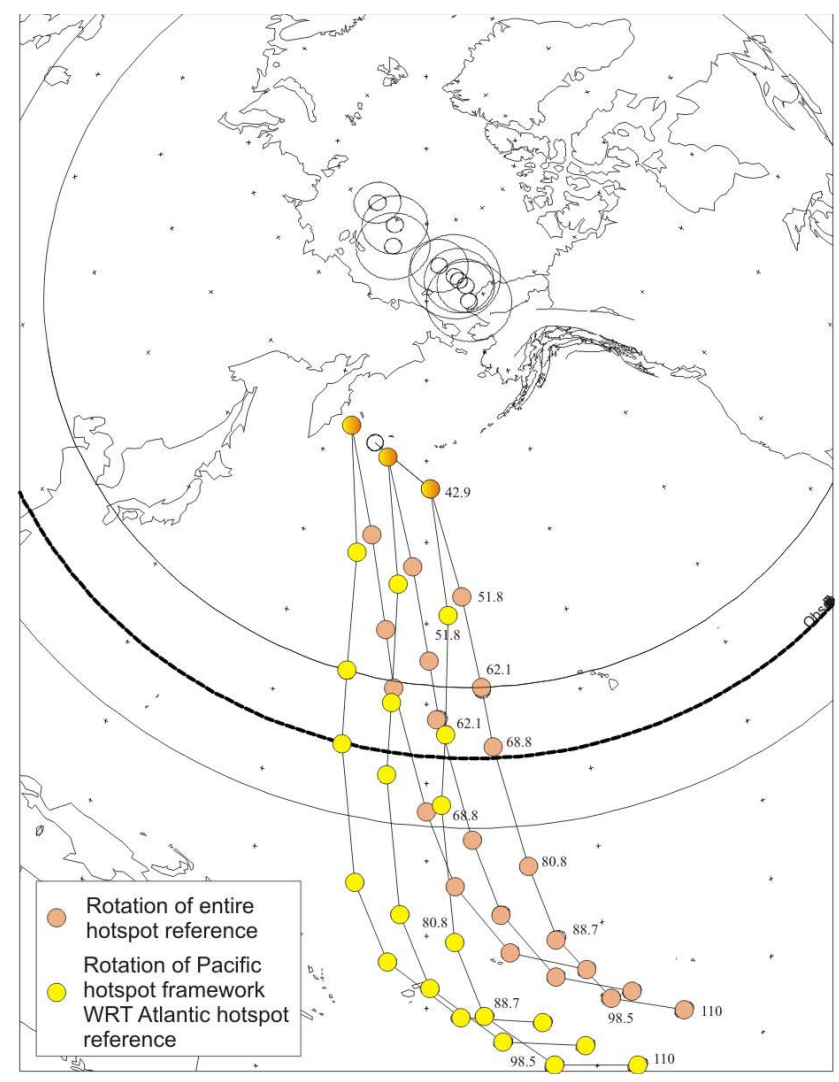

Fig. A1. The APWP for North America and associated 95\% confidences from Besse and Courtillot (1991) are compared with the observed B component paleolatitude and uncertainity compared with a series of terrane trajectories. Yellow circles are calculated assuming the TPW presented in Torsvik et al. (2002) and docking with the North America plate at 20, 30 or $40 \mathrm{Ma}$. Orange circles lay along terrane trajectories calculated assuming a relative rotation of the $\mathrm{Pa}$ cific Hotspots with respect to other hotspots as suggested by Tarduno et al. (2003). The plate trajectories only involve recalculated finite rotations for the Pacific, Kula and Izanagi plates. Other plates, such as the proposed Vetlovka (Konstantinovskaia, 2001) are not modeled because of a lack of magnetic isochron derived finite rotations for this particular plate. Most reconstructions involving other oceanic plates in the northwest Pacific basin do not show major relative motion between such smaller oceanic plates and the modeled oceanic plates; therefore the terrane trajectories shown in this figure would be similar to those calculated for terrane migration including plates such as the Vetlovka.

and

$$
\begin{aligned}
\mathrm{NAM}_{\mathrm{NUL}}^{T 1} \Re_{\mathrm{KAM}}^{T 2}= & \underset{\mathrm{NAM}}{T 1} \Re_{\mathrm{AFR}}^{T 2} \oplus\left(-\left({ }_{\mathrm{HS} 1}^{T 1} \Re_{\mathrm{AFR}}^{T 2}\right)\right) \oplus_{\mathrm{HS} 1}^{T 1} \Re_{\mathrm{GXS}}^{T 2} \\
& \oplus_{\mathrm{GXS}}^{T 1} \Re_{\mathrm{HS} 2}^{T 2} \oplus_{\mathrm{HS} 2}^{T 1} \Re_{\mathrm{PAC}}^{T 2} \oplus_{\mathrm{PAC}}^{T 1} \Re_{\mathrm{KUL}}^{T 2}
\end{aligned}
$$

The predicted terrane trajectories from this modified analysis are shown in Fig. A1.
An additional key assumption in constructing a terrane trajectory is the location and age of accretion (Debiche et al., 1987). Presently the most accurately constrained age of accretion has been determined for the Olyutorskiy on the basis of single zircon crystal fission-track analysis. The age of accretion of the Olyutorskiy terrane is estimated now as middle Eocene based on new ages determined for the rocks in the terrane thrust sheets and age of intrusions which suture the thrust (Soloviev et al., 2002; Garver et al., 2000; Alexeiev et al., 2006). We constructed three terrane trajectory models each assuming the age of accretion to be 20,30 or $40 \mathrm{Ma}$. To model the paleomagnetic result we assumed a displacement history for the terrane that consists of being transported with the Izanagi plate between 110.1 and $85 \mathrm{Ma}$ followed by Kula plate motion between the beginning of Campanian $(\sim 85 \mathrm{Ma})$ and the time of accretion. In each accretion model, motion with the Pacific plate occurs between 43 and the age of docking.

Acknowledgements. This work could not be completed without a joint field program including our colleagues from the Geological Institute Academy of Science of Russia, Moscow, P. P. Shirshov Institute of Oceanology, Moscow and the Volcano and Geological Institute, Petropavlovsk. We wish to thank Maxim Alexyutin, Paul Layer and David Stone for their helpful and excellent reviews of this manuscript. Support for this work came from NSF-9706446 and the Russian Academy of Sciences. The financial and logistical support provided by the GeoForschungsZentrum Potsdam is gratefully ackowledged. Funding was provided by the Russian Academy of Sciences and United States National Science Foundation, Crustal Tectonics Program, for this cooperative field program (NSF awards EAR-9219271, EAR 97-06446, INTAS-96-1880, RFBR-99-05-65649 and RFBR-05-05-64158), with additional generous support from the University of Pittsburgh.

\section{A brief personal memory of Dr. Parfenov}

(WH) I had the pleasure to initially correspond with Dr. Parfenov while completing my Ph.D. at Stanford University during the early 1980 's. During that time, after reviewing the literature describing the geology, geophysics and tectonics of the northeastern USSR I had written Dr. Parfenov a letter, somewhat unfocused, but full of idealism and interest in his research. It was my pleasure to receive a very thoughtful reply to my initial correspondence and a thick collection of Russian language articles written by Dr. Parfenov and his colleagues. These articles were enormously useful to my understanding the geological history of this large region of Eurasia, and are carefully preserved today. After several earlier visits to the USSR, in 1987 I met Dr. Parfenov for the first time while attended the first plate tectonics conference held in the USSR, at YuzhnoSakhalinsk on Sakhalin Island. It was a pleasure to meet and talk with Dr. Parfenov about his ideas regarding the plate tectonic history of the USSR. At that time a number of research teams in the USSR were actively, and somewhat discretely, applying plate tectonics to the geodynamics of this vast region. I remember accompanying my Russian colleagues on a pleasant picnic and swim held 
in an Elysian pastoral scene near a local river. A group broke away to enjoy swimming in the wonderful blue cool river on this warm afternoon. It was a joke for our group, called back and forth numerous times in Russian, that the "Mobilists" would float, but the "Fixists" should beware, they would no doubt immediately sink to the bottom of the river! Dr. Parfenov continued to aid my research with thoughtful discussions at international meetings and by generously providing copies of his significant and important publications, such as his geodynamic reconstructions of northeastern Russia. His presentations were "must-attend" events for me and my graduate students at geoscience meetings in Anchorage, San Francisco or international locations. My coauthors and I are honored to contribute to this volume in Dr. Parfenov's honor. A scholar and gentleman, Dr. Parfenov is fondly remembered and greatly missed.

\section{References}

Aleksandrov, A. A.: Thrust faults and imbricated structures in Koryak highland, Moscow, Nauka Publishers, 121 pp., 1978 (in Russian).

Aleksandrov, A. A., Bogdanov, N. A., Byalobzhesky, S. G., Markov, M. S., Tilman, S. M., Khain, V. E., and Chekhov, A. D.: New data on tectonics of Koryak Highland, Geotektonika, 5, 60-72, 1975 (in Russian).

Aleksandrov, A. A., Bogdanov, N. A., Palanjan, S. A., and Chekhovich, V. D.: On the tectonics of the Northern part of the Olyutorsky zone of the Koryak Highland, Geotektonika, 3, 111122, 1980 (in Russian).

Alekseyev, E. S.: Main features of the development and structure of the northern part of the Koryak Highland, Geotektonika, 1, 85-96, 1979 (in Russian).

Alekseyev, E. S.: The Kuyul Serpentinite Melange and the structure of the Talovsk-Maynska Zone (Koryak Mountains), Geotektonika, 2, 68-78, 1981 (in Russian).

Alekseyev, E. S.; Geodynamics of the ocean-continent transition zone on the example of Late Mesozoic and Cenozoic history of the Southern part of the Koryak Highland, Geotektonica, 3, 102114,, 1987 (in Russian).

Alexeiev, D. V., Gaedicke, C., Tsukanov, N. V., and Freitag, R.: Collision of the Kronotskiy arc at the NE Eurasia margin and structural evolution of the Kamchatka-Aleutian junction, Int. J. Earth Sci. (Geol Rundsch), 95, 977-993, 2006.

Astrahantzev, O. V., Kazimirov, A. D., and Heiphetz, A. M.: Tectonics of the northern part of the Olyutorsky zone; In: Geology of the northwestern part of the Pacific belt, edited by: Pusharovsky, Yu. M., Academy of Sciences of the USSR Publishers, Moscow, 161-183,, 1987 (in Russian).

Avé Lallemant, H. G. and Oldow, J. S.: Active displacement partitioning and arc-parallel extension of the Aleutian volcanic arc based on Global Positioning System geodesy and kinematic analysis, Geology, 28(8), 739-742, 2000.

Bazhenov, M., Burtman, V., Krezhovskikh, O., and Shapiro, M.: Paleomagnetism of Paleogene rocks of the Central-East Kamchatka and Komanorsky Islands: tectonic implications, Tectonophysics, 201, 157-173, 1992a.

Bazhenov, M. L., Burtman, V. S., Krezhovskikh, O. A., and Shapiro, M. N.: Paleomagnetism of Paleocene rocks from the Eastern Kamchatka and Komandorsky Islands: implications to tectonics, Tectonophysics, 201, 157-174, 1992b.
Besse, J. and Courtillot, V.: Revised and synthetic polar wander paths of the African, Eurasian, North American and Indian plates, and true polar wander since $200 \mathrm{Ma}$, J. Geophys. Res. 96, 4029-4050, 1991.

Bingham, C.: An antipodally symmetric distribution on a sphere, The Annals of Statistics, 2, 1201-1225, 1974.

Bogdanov, N. A. and Fedorchuk, A. V.: Geochemistry of Cretaceous oceanic basalts of the Olutorsky range (Bering Sea), Ofioliti, 12(1), 113-124, 1987.

Byalobzhesky, S. G.: Tectonics of Koryak Ridge, Cand. Sci. thesis, Moscow, Geological Institute Academy of Sciences of USSR, 24 pp., 1979 (in Russian).

Chapman, M. E. and Solomon, S. C.: North American-Eurasian Plate Boundary in Northeast Asia, J. Geophys. Res., 81, 921930, 1976.

Chekhovich, V. D., Kovalenko, D. V., and Ledneva, G.: Cenozoic history of the Bering Sea and its northwest margin, The Island Arc, 8, 168-180, 1999.

Courtillot, V., Davaille, A., Besse, J., and Stock, J.: Three distinct types of hotspots in the Earth's mantle, Earth Planet. Sc. Lett., 205, 295-308, 2003.

Cook, D. B., Fujita, K., and McMullen, C. A.: Present-day plate interactions in northeast Asia: North American, Eurasian, and Okhotsk plates, J. Geodyn., 6, 33-51, 1986.

Cox, A. and Hart, R. B.: Plate Tectonics, how it works, Blackwell Scientific Publications, Inc. Oxford, 1986.

Debiche, M. G., Cox, A., and Engebretson, D.: The motion of allochthonous terranes, Geological Society of America Special Paper, 207, 49 pp., 1987.

Demarest, H. H.: Error analysis for the determination of tectonic rotation from paleomagnetic data, J. Geophys. Res. 88, 43214328, 1983.

Didenko A., Harbert, W., and Stavsky, A.: Paleomagnetism of the Khatyrka and Maynitsky superterranes, Koryak Highland, Far Eastern Russia, Tectonophysics, 220, 141-155, 1993.

Engebretson, D. C., Cox, A., and Gordon, R. G.: Relative motions between oceanic and continental plates in the Pacific basin, Geological Society of America Special Paper, 206, 59 pp., 1985.

Ermakov, B. V. and Souprounenko, O. I.: Structure and environment of origin of the Late Cretaceous and Miocene flish of Koryak-Kamchatka area, Sovetskaya Geologia, 12, 53-65, 1975 (in Russian)

Fisher, R. A.: Dispersion on a Sphere, P. Roy. Soc. Lond. A Mat., 217, 295-305, 1953.

Fedorchuk, A. V.: The Olyutor igneous complex of the ConiacianEarly Santonian, in: Geology of the southern Koryak Range, edited by: Tilman, S. M., 78-94, Academy of Sciences of the USSR, 1987.

Freitag, R., Gaedicke, C., Baranov, B., and Tsukanov, N.: Collisional processes at the junction of the Aleutian-Kamchatka arcs: New evidence from fission track analysis and field observations, Terra Nova, 13, 433-442, 2001.

Fujita, K. and Newberry, J. T.: Tectonic evolution of northeastern Siberia and adjacent regions, Tectonophysics, 89, 337-357. 1982.

Garver, J. I., Soloviev, A. V., Bullen, M. E., and Brandon, M. T.: Towards a more complete record of magmatism and exhumation in continental arcs, using detrital fission-track thermochrometry, Phys. Chem. Earth Pt. A, 15, 565-570, 2000. 
Gelman, M. L. and Bychkov, Yu. M.: Triassic volcanites of Kankaran ridge and zonation of geosynclinal volcanics in Koryak Highland, Pacific Geology, 1, 53-63, 1988 (in Russian).

Gaeidicke, C., Alexeiev, D., Baranov, B., Seliverstov, N., Alexeiev, D., Tsukanov, N., and Freitag, R.: Structure of an active arc-continent collision area: the Aleutian-Kamchatka junction, Tectonophysics, 325, 63-75, 2000.

Geist, E. L. and Scholl, D. W.: Large-scale deformation related to the collision of the Aleutian Arc with Kamchatka, Tectonics, 13, 538-560, 1994.

Grigoriev, V. N., Krylov, K. A., and Sokolov, S. D.: Upper JurassicLower Cretaceous sediments of central part of Koryak Highland, in: Essays on Geology of Eastern USSR, edited by: Pusharovsky, Yu. M., Moscow, Nauka Publ., 58-80, 1986 (in Russian).

Grigoriev, V. N., Krylov, K. A., and Sokolov, S. D.: Basic formational types of the Mesozoic sequences from Koryak Highland and their tectonic implications, in: Early geosynclinal formations and structures, edited by: Pusharovsky, Yu. M., Trans. of Geological Institute Ac. Sci. USSR, Moscow, Nauka Publ., 417, 138-245, 1987.

Grigoriev, V. N., Krylov, K. A., Sokolov, S. D., and Tsukanov, N. V.: Terranes in accretional structure of Koryak-Kamchatka region, Abstr. in: Tectonics and mineral resources of the North-Eastern part USSR, Magadan, SVKNII DVO Academy of Sciences of USSR, 58-59, 1990 (in Russian).

Harbert, W., Kepezhinskas, P., Krylov, K. Grigoriev, V., Sokolov, S., Aleksutin, M., Heiphetz, A., and Layer, P.: Paleomagnetism and tectonics of the Kamchatka region, northeastern Russia: Implications for the development and evolution of the northwest Pacific basin, Polarforschung, 68, 297-308, 1998 (erschienen 2000).

Heiphetz, A., Harbert, W., and Savostin, L.: Reconnaissance Paleomagnetism of the Olyutorsky superterrane, Northeast Russia, Proceedings of the International Conference on Arctic Margins MMS 94-0040, 223-228, 1994.

Heiphetz, A., Harbert, W., and Savostin, L.: Reconnaissance Paleomagnetism of the Olyutorsky Supperterrane, NE Russia, in: Proceedings International Conference on Arctic Margins, edited by: Thurston, D. K., and Fujita, K., Anchorage, Alaska, US Department of the Interior, 223-228, 1992a.

Heiphetz, A., Harbert, W., and Layer, P.: Preliminary Reconnaissance Paleomagetism of some Late Mesozoic Ophiolites, Kuyul Region, Northern Koryak Supperterrane, Russia, in: Proceedings International Conference on Arctic Margins, edited by: Thurston, D. K. and Fujita, K., Anchorage, Alaska, US Department of the Interior, 229-234, 1992b.

Irving, E. and Irving, G. A.: Apparent polar wander paths Carboniferous through Cenozoic and the assembly of Gondwana, Geophys. Surv., 5, 141-188, 1982.

Konstantinovskaia, E. A.: Arc-continent collision and subduction reversal in the Cenozoic evolution of the Northwest Pacific: An example from Kamchatka (NE Russia), Tectonophysics, 333, 75-94, 2001.

Kazimirov, A. D.: Nappes of the East Koryak Highland and their structural - formational homologues, Trans. of Geological Institute Ac. Sci. USSR, Moscow, Nauka Publ., 391, 112 pp., 1985 (in Russian).

Kazimirov, A. D., Krylov, K. A., and Fedorov, P. I.: Tectonic evolution of the back-arc basins (using south of the Koryak Highland as an example), in: Essays of Geology of the northwestern part of the Pacific belt, edited by: Pusharovsky, Yu. M., Academy of Sciences of the USSR, Moscow, 200-225, 1987 (in Russian).

Khanchuk, A. I. , Sokolov, S. D., Grigoryev, V. N., Golozubov, V. V., Govorov, G. I., Krylov, K. A., Kurnosov, V. B., Panchenko, I. V., Pralnikova, I. E., and Chudaev, O. V.: Kuyul ophiolite terrane, Vladivostok, Ac. Sci. Publ., 1990 (in Russian).

Khramov, A. N.: Paleomagnetology, Springer-Verlag, Berlin, 308 pp., 1987.

Khramov, A. N.: Paleomagnetism and Problems of Accretion Tectonics Northwest of Mobile PacificOcean, in Paleomagnetism and Accretion Tectonics, Leningrad, VNIGRI Publ., 141-152, 1988 (in Russian).

Konstantinovskaia, E. A.: Arc-continent collision and subduction reversal in the Cenozoic evolution of the Northwest Pacific: An example from Kamchatka (NE Russia), Tectonophysics, 333, 75-94, 2001.

Kovalenko, D. V. and Kravchenko-Berezhnoy, I. R.: Paleomagnetism and tectonics of Karaginsky Island, Bering Sea, The Island Arc, 8, 426-439, 1999.

Kovalenko, D. V.: Paleomagnetism of the geological complexes of Kamchatka and southern Koryakia, Moscow, Scientific World, 255 pp., 2003 (in Russian).

Kovalenko, D. V.: Paleomagnetism and kinematics of the central part of the Olytorsky Range (Koryak Highlands), Geotectonics, 3, 82-92, 1996 (in Russian).

Kovalenko, D. V.: Geological interpretation of the paleomagnetic data from Cretaceous - Paleogene rocks of the southern Koryak Highland, Cand. Sci. thesis, Instituite of Lithosphere, Ac. Sci. Rus., 1992 (in Russian).

Kravchenko-Berezhnoy, I. R., Chamov, N. P., and Scherbinina, E. A.: MORB-like tholeiites in a late Eocene turbidite sequence on Karaginsky Island (the Western Bering Sea), Ofioliti, 15, 231250, 1990.

Krylov, K. A., Ruzhentzev, S. V., and Sokolov, S. D.: Accretion of oceanic complexes in Koryak Highland, in: Geological history territory of USSR and plate tectonics, edited by: Zonenchain, L. P. and Pristavakina, E., Moscow, Nauka Publ., 111-120, 1989 (in Russian).

Levashova, N. and Bazhenov, M.: Late Cretaceous paleomagnetism of the East Ranges island arc complex, Kamchatka: Implications for terrane movements and kinematics of the northwest Pacific, J. Geophys. Res., 102, 24 843-24 857, 1997.

Levashova, N. M., Shapiro, M. N., and Bazhenov, M. L.: Late Cretaceous paleomagnetic data from the Median Range of Kamchatka, Russia: tectonic implications, Earth Planet. Sc. Lett., 163, 235-246, 1998.

Mackey, K. G., Fujita, K., Gunbina, L. V., Kovalev, V. N., Imaev, V. S., Koz'min, B. M., and Imaeva, L. P.:, Seismicity of the Bering Strait Region: Evidence for a Bering Block, Geology, 25, 979982, 1997.

McElfresh, S. B. Z., Harbert, W., Ku, C.-Y., and Lin, J.-S.: Stress modeling of tectonic blocks at Cape Kamchatka, Russia using principal stress proxies from high resolution SAR: New evidence for the Komandorskiy block, 354, 239-256, 2002.

Migovich, I. M.: Tectonic development Penzhin-Anadyr folded zone, Cand. Sci. thesis, Leningrad, VSEGEI, 1972 (in Russian).

Mitrofanov, N. P.: Vatyna overthrust in the central Koryak fold belt, Geol. Geofiz., 4, 144-149, 1977 (in Russian).

Mitrofanov, N. P. and Sheludchenko, S. P.: On the age of terrige- 
neous rocks on the southwest of the central Koryak zone, Geol. Geofiz., 4, 128-131, 1981 (in Russian).

Moroz, Yu. M.: Deep structure of the South-Westrn part of Koryak Highland, Sovietskaia Geologia, 5, 118-123, 1987 (in Russian).

Natal'in, B. A., Parfenov, L. M., Vrublevsky, A. A., Karsakov, L. P., and Yushmanov, V. V.: Main fault systems of the Soviet Far East, Philos. T. R. Soc. Lond., A317, 276-275, 1986.

Nekrasov, G. E.: Tectonic and magmatism of Taygonos and NorthWestern Kamchatka, Moscow, Nauka Publ., 1976.

Nokleberg, W. J., West, T. D., Dawson, K. M., Shipikerman, V. I., Bundtzen, T. K., Parfenov, L. M., Monger, J. W. H., Ratkin, V. V., Baranov, B. V., Byalobzhesky, S. G., Diggles, M. F., Eremin, R. A., Fujita, K., Gordey, S. P., Gorodinsky, M. E., Goryachev, N. A., Feeney, T. D., Frolov, Y. F., Grantz, A., Khanchuk, A. I., Koch, R. D., Natalin, B. A., Natapov, L. M., Norton, I. O., Patton Jr., W. W., Plafker, G., Pozdeev, A. I., Rozenblum, I. S., Scholl, D. W., Sokolv, S. D., Sosunov, G. M., Stone, D. B., Tabor, R. W., Tsukanov, N. V., and Vallier, T. L.: Summary Terrane, Mineral Deposit, and Metallogenic Belt Maps of the Russian Far East, Alaska, and the Canadian Cordillera, US Geological Survey Open File Report, 98-136, 1998.

Nokleberg, W. J., Bundtzen, T. K., Dawson, K. M., Eremin, R. A., Goryachev, N. A., Koch, R. D., Ratkin, V. V ., Rozenblum, I. S., Shipikerman, V. I., Frolov, Y. F., Gorodinsky, M. E., Melnikov, V. I., Diggles, M. F., Ognyanov, N. V., Petrachenko, E. D., Petrachenko, R. I., Pozdeev, A. I., Ross, K. V., Wood, D. H., Grybeck, D., Khanchuk, A. I., Kovbas, L. I., Nekrasov, I. Y., and Sidorov, A. A.: Significant Metalliferous and Selected NonMetalliferous lode Deposits and Placer Districts for the Russian Far East, Alaska, and the Canadian Cordillera, US Geological Survey Open File Report, 96-513-B, 1997.

Parfenov, L. M. and Natal'in, B. A.: Mesozoic accretion and collision tectonics in northeast Asia, in: Tectonostratigraphic terranes of the Circum-Pacific region, edited by: Howell, D. G., CircumPacific Countil for Energy and Mineral Resources, Houston, 363-373, 1985.

Parfenov, L. M. and Natal'in, B. A., Mesozoic tectonic evolution of Northeastern Asia, Tectonophysics, 127, 291-304, 1986.

Pechersky, D., Levashova, N., Shapiro, M., Bazhenov M., and Sharonova, Z.: Paleomagnetism of Paleogene volcanic series of the Kamchatsky Mys Peninsula, east Kamchatka: The motion of an active island arc, Tectonophysics, 273, 219-238, 1997.

Raznitsin, Yu. N., Khubunaya, S. A., and Tsukanov, N. V.: Tectonics of the eastern part of Kronotsky Peninsula and associational assignement of basalts (Kamchatka), Geotectonics, 19, 64-74, 1985.

Riegel, S. A., Fujita, K., Koz'min, B. M., Imaev, S., and Cook, D. B.: Extrusion tectonics of the Okhotsk plate, northeast Asia, Geophys. Res. Lett., 20, 607-610, 1993.

Ruzhentsev, S. V., Byalobzhesky, S. G., Kazimirov, A. D., and Sokolov, S. D.: Tectonic nappes and palinspastics of the Koryak ridge, in: Tectonic development of the Earth crust and faults, edited by: Peive, A. A., Moscow, Nauka Publ., 63-80, 1979 (in Russian).

Ruzhentsev, S. V., Byalobzhesky, S. G., Grigoriev, V. N., Kazimirov, A. D., Peive, A. A., and Sokolov, S. D.: Tectonics of Koryak ridge, in: Essays on Tectonics of the Koryak Highland, Academy of Sciences of the USSR, Moscow, Nauka Publ., 136189, 1982 (in Russian).
Shapiro, M. N.: Tectonic development of the Eastern margin of Kamchatka, Moscow, Nauka Publ., 124 pp., 1976 (in Russian).

Shapiro, M. N. and Fedorov, P. I: Basalts in the terrigeneous rocks of the Sredinny Range (Kamchatka), Izvestiya VUZov, Geologiya i razvedka, 5, 22-29, 1985 (in Russian).

Shapiro, M. N., Yermakov, V. A., Shantser, A. E., Shuldiner, V. I., Khanchuk, A. I., and Vysotsky, S. V.: Tectonic evolution of the Kamchatka arc, Nauka Publishers, Moscow, 247 pp., 1987 (in Russian).

Shapiro, M. N., Slyadnev, B. I., and Lander, A. V.: Thrustimbricated - structure of northern part of the Eastern-Kamchatka antiklinorium, Geotektonika, 6, 84-93, 1984 (in Russian).

Shapiro, M. N. and Ganelin, V. G.: Paleogeodynamic interrelations in the large blocks of the Mesozoic of the north-eastern USSR, Geotektonika, 5, 94-104, 1988 (in Russian).

Shapiro, M. N.: The upper Cretaceous Achaivayamian-Valaginian volcanic arc and kinematics of the North Pacific plates, Geotectonics, 29, 52-64, 1995.

Shapiro, M. N., Soloviev, A. V., Garver, G. I., and Brandon, M. T.: Sources of Zircon from Cretaceous and lower Paleogene terrigenous sequences of the southern Koryak upland and western Kamchatka, Lithol. Miner. Resour., 36, 322-336, 2001.

Sokolov, S. D.: Accretionary tectonics of the Koryak-Chukotsky segment of the Pacific belt, D.Sc. thesis, Geological Institute Ac. of Sci. of the USSR, Moscow, 1988 (in Russian).

Sokolov, S. D.: Accretionary tectonics of the Koryak-Chukotka segment of the Pacific belt, Trans. of Geological Institute Russsian Academy of Sciences, Moscow, Nauka, 479 pp., 1992 (in Russian).

Sokolov, S. D., Grigoriev, V. N., Zinkevich, V. P., Kazimirov, A. D., Krylov, K. A., Peive, A. A., and Tzukanov, N. A.: Accretion and tectonic layering in structures Koryak Highland and Kamchatka, in: Main problems of tectonics of the USSR, Moscow, Nauka, 111-119, 1988 (in Russian).

Soloviev, A. V., Shapiro, M. N., Garver, J. I., Shcherbinina, E., and Kravchenko-Berezhnoy, I. R.: New age data from the Lesnaya Group: A key to understanding the timing of arc-continent collision, Kamchatka, Russia, The Island Arc, 11, 79-90, 2002.

Soloviev, A. V., Hourigan, J. K., Brandon, M. T., Garver, J. I., and Grigorenko, E. S.: The Age of the Baraba Formation Inferred from the P/Ub (SHRIMP) dating (Sredinnyi Range, Kamchatka): Geological Consequences, Stratigr. Geo. Correl., 12, 418-424, 2004.

Stavsky, A. P., Chekhovich, V. D., and Kononov, M. V.: Plate tectonics and palinspastic reconstructions of the Anadyr Koryak region, northeast USSR, Tectonics, 9, 81-101, 1990.

Tarduno, J. A., Duncan, R. A., Scholl, D. W., Cottrell, R. D., Steinberger, B., Thordarson, T., Kerr, B. C., Neal, C. R., Frey, F. A., Torii, M., and Carvallo, C.: The Emperor Seamounts: Southward motion of the Hawaiian hotspot plume in Earth's Mantle, Science, 301, 1064-1069, 2003.

Tarduno, J. A. and Gee, J.: Large-scale motion between Pacific and Atlantic hotspots, Nature, 378, 477-480, 1995.

Torsvik, T. H., Van der Voo, R., and Redfield, T. F.: Relative hotspot motions versus True Polar Wander, Earth Planet. Sc. Lett., 202, 185-200, 2002.

Tsukanov, N. V. and Fedorchuk, A..: Ophiolites Of The Eastern Kamchatka: Implications For Paleotectonics Of The Northwest Pacific Margin, AGU Fall 2000 Invited Poster V72B-06, 2000. 
Tsukanov, N. V: Tectonic evolution of Kamchatka perioceanic area in the Mesozoic-Early Cenozoic, Nauka, Moscow, 1991 (in Russian).

Tsukanov, N. V. and Fedorchuk, A. V: Oceanic complexes in the structure of the Kumroch Range, Kamchatka, Transaction of USSR Academy of Sciences, Earth Science Section, 304, 943948, 1989.

Watson, B. F. and Fujita, K.: Tectonic Evolution of Kamchatka and the Sea of Okhotsk and Implications for the Pacific Basin, in: Tectonostratigraphic terranes of the circum-Pacific region, edited by: Howell, D. G., The Circum-Pacific Council for Energy and Mineral Resources, Houston, 1, 333-348, 1985.
Zinkevich, V. P., Konstantinovskaya, E. A., Magakyan, R., and Tsukanov, N. V.: Accretionary structure of the Eastern Kamchatka, Doklady USSR Academy of Science, 312, 1186-1190, 1990 (in Russian).

Zonenshain, L. P., Kuzmin, M. I., and Natapov, L. M.: Geology of the USSR: A plate tectonic synthesis, American Geophysical Union, Geodynamics Series, 21, 1991.

Zonenshain, L. P., Kononov, M. V., and Savostin, L. A.: Pacific and Kula/Eurasian relative motions during the last $130 \mathrm{Ma}$ and their bearing on orogensis in northeast Asia, in: Circum-Pacific Orogenic Belts and Evolution of the Pacific Ocean Basin, edited by: Monger, J. W. H. and Francheteau, J., Geodynamics Series, 18, 29-47, 1987. 